\title{
PERAN HIRARKI GEREJA \\ DALAM MENINGKATKAN PERAN SOSIAL-POLITIK \\ PARA POLITISI KATOLIK SEBAGAI BENTUK PERWUJUDAN IMAN
}

Oleh: Frederikus Dhedhu

\begin{abstract}
Abstrak:
Dunia Politik adalah dunia yang selalu diwarnai dengan pertarungan antara memperjuangkan kepentingan umum dan memperjuangkan kepentingan pribadi atau kelompok. Idealnya kepentingan umum atau kesejahteraan bersama harus diutamakan dan diperjuangkan. Tetapi sering kali kepentingan pribadi dan kelompok lebih kuat mempengaruhi kebijakan yang diambil oleh para politisi termasuk para politisi Katolik. Kebenaran, keadilan, demokrasi dan hak-hak asasi masyarakat dikangkangi demi ambisi politik sektarian. Dalam konteks itu, Hirarki Gereja terpanggil untuk memberi motivasi dan inspirasi kepada para politisi Katolik untuk memposisikan dirinya sebagai sosok strategis yang mampu memainkan peran sosial-politiknya demi kesejahteraan masyarakat sebagai bentuk konkrit perwujudan iman dengan kekuatan moralitas Katolik.
\end{abstract}

Kata Kunci : Sosial-Politik, Politisi, Perwujudan Iman, Hirarki

\section{Pendahuluan}

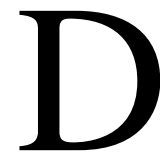
ewasa ini masih terdapat konsep atau pandangan yang keliru tentang peran agama dalam menghadirkan keselamatan bagi para penganutnya. Agama dipahami secara sangat sempit bahkan tidak jarang agama dibelokkan ke jalur destruktif. Kekeliruan yang tidak pernah diperbaiki, dalam perjalanan waktu, melahirkan paham yang salah tentang peran agama. Di antaranya berkembangnya paham Individualisme keselamatan. Paham ini menegaskan keselamatan merupakan urusan pribadi, sehingga setiap orang berjuang mengusahakan keselamatan masing-masing secara individual saja, sehingga tata susunan masyarakat atau konkritnya masalah-masalah aktual dunia bukan urusan agama. Di samping itu juga berkembang konsep spiritualisme agama, di mana agama dipahami hanya berurusan dengan keselamatan jiwa di akhirat bukan dengan masalah sosial: kebutuhan pokok, sistem sosial yang menjamin keadilan, kemiskinan dan sebagainya. Selanjutnya masih menguatnya konsep supranaturalisme agama di mana tugas agama adalah menghantar orang ke surga, bukan ikut campur tangan dalam kehidupan masyarakat di dunia (Sudarmanto, 1989:76).

Konsili Vatikan II berhasil menempatkan Gereja pada posisi yang tepat yakni Gereja berada di dunia. Tanpa dunia tidak ada Gereja. Karena itu konsep-konsep tersebut telah ditinggalkan oleh Gereja. Saat ini Gereja memandang bahwa dunia dengan segala 
problematiknya merupakan medan di mana Kerajaan Allah dibangun. Dasar teologis satusatunya bagi Gereja untuk menilai semua realitas kehidupan manusia dan selanjutnya berjuang untuk terlibat dalam dunia adalah peristiwa Inkarnasi. Peristiwa Inkarnasi menjadi titik tolak bagi Gereja untuk menilai secara positip realitas duniawi sebagai sarana untuk mencapai keselamatan yang utuh. LG No. 8 mengatakan:

Kristus satu-satunya pengantara di dunia ini telah membentuk GerejaNya yang Kudus, persekutuan iman, harapan dan cinta kasih, sebagai himpunan yang kelihatan. Ia tiada hentinya memelihara Gereja. Melalui Gereja Ia melimpahkan kebenaran dan rahmat kepada semua orang. Adapun serikat yang dilengkapi dengan jabatan hirarkis dan Tubuh Mistik Kristus, kelompok yang nampak dan persekutuan rohani, Gereja di dunia dan Gereja yang diperkaya dengan kurniakurnia surgawi, janganlah dipandang sebagai dua hal, melainkan semua itu merupakan satu kenyataan yang kompleks dan terwujudkan karena perpaduan antara unsur manusiawi dan ilahi.

Dengan konsep baru tersebut Gereja menjadikan semua realitas kemanusiaan termasuk realitas politik menjadi sarana keselamatan. Gereja tidak dipanggil untuk "lari dari dunia" tetapi diundang untuk "masuk dalam dunia". Karena itu berbicara tentang pewartaan Injil tanpa mengakui dunia sebagai tempat untuk menjadikan nilai-nilai Injil hidup dalam keseharian dan mentalitas umat, dalam struktur-struktur sosial masyarakat, merupakan suatu pengkhianatan atas misi Gereja itu sendiri. Sebab bidang politik merupakan cakupan tanggung jawab karya pastoral Gereja.

Itulah sebabnya karya pastoral Gereja selalu memiliki ciri sosio-politis, dimana Gereja dipanggil untuk mengkonkritkan "tanggung-jawab sosial-politiknya". Tanggung jawab sosialpolitik berhubugan dengan pelayanan Gereja demi pembebasan masyarakat dari berbagai macam tekanan politik dan pengangkangan hak-hak asasi masyarakat. Karya Pastoral Gereja harus menyentuh manusia dalam situasinya yang konkrit: dimana ia hidup dan kapan ia hidup. Dunia adalah tempat manusia hidup. Dunia diciptakan oleh Allah dalam dan karena cintaNya yang kekal. Dunia dilihat sebagai "locus teologicus" dan partner dari gereja. Tanpa dunia tidak ada gereja. Karena itu gereja dan dunia menghasilkan sejarah bersama, berjalan bersama menuju kesempurnaan Kerajaan Allah sebagaimana diwartakan oleh Yesus semasa hidupNya di dunia.

Gereja bertanggung jawab untuk mendidik umatnya untuk mampu menggarami dunia politik dengan nilai-nilai kristiani. Dalam rangka memaksimalkan peran awam dalam dunia politik serta pemaknaan dunia politik yang lebih mempromosikan harkat dan martabat manusia, maka peran pendampingan hirarki menjadi penting dan mendesak. Peran Hirarki (uskup dan imam) pertama-tama terfokus pada tataran membangun motivasi dan komitmen awam untuk berpolitik dengan acuan pada nilai-nilai Injil. Kalau demikian tidak ada politik kristiani, tetapi yang ada hanyalah politisi katolik yang memperjuangkan hadirnya nilai-nilai Kristiani dalam setiap kebjikan politik. Nilai-nilai Kristiani tidak pernah bertentangan dengan nilai-nilai universal yang menjadi landasan hidup manusia pada umumnya.

\section{POLITIK}




\subsection{Pengertian Politik}

Kata "politik" berasal dari kaya Yunani "Ta politika" yang berarti hal-hal yang berhubungan dengan " polis" (negara kota). Selanjutnya Aristoteles telah mengembangkan pengertian "polis" sebagai masyarakat dengan hak yang sama untuk menata kehidupan bersama. Dengan demikian politik berarti menata kehidupan bersama dalam kemerdekaan dan kesamaan hak dengan berpedoman pada peri kemanusiaan. Dasar kemanusiaan diangkat ke permukaan untuk menunjukkan bahwa setiap pribadi manusia yang membentuk satu-kesatuan kelompok masyarakat memiliki martabat yang sama sebagai manusia (Go,1989:1)

Dalam perkembangan selanjutnya terminologi politik dikaitkan dengan kegiatan-kegiatan yang berhubungan dengan kekuasaan, yakni cara-cara untuk mendapatkan dan mempertahankannya. Politik dalam arti sempit berhubungan dengan semua kegiatan yang mempengaruhi atau mencapai pembagian kekuasaan. Politik berkaitan langsung dengan pemerintahan. Partai-partai politik dengan program dan kebijakannya berusaha memperoleh atau mempertahankan kekuasaan dan pemerintahan.

Sedangkan politik dalam arti luas menunjuk pada keseluruhan keterlibatan dalam berbagai pelayanan umum dan dampaknya dalam bidang-bidang ekonomi, sosial, budaya dan pendidikan. Ada kegiatan yang merupakan kegiatan non-partai tetapi dampak politisnya jelas, seperti perjuangan untuk membela hak asasi manusia, perjuangan untuk membela kebenaran dan keadilan.

\subsection{Politisi Katolik}

Politik memiliki otonomi. Karena itu para politisi Katolik tidak bertindak atas nama Gereja, baik umat maupun Hirarki, melainkan atas prakarsa dan atas nama pribadi yang dituntun oleh hati nurani dan berdasarkan nilai-nilai Injil yang dihayatinya. Karena itu tidak ada politik Katolik. Yang ada adalah politisi Katolik yang terpanggil untuk mengusahakan kesejahteraan umum melalui pelayanan publik yang berkualitas dan relevaan, membangun institusi-institusi yang lebih adil dan melakukan aksi dan tindakan yang dipahami sebagai integritas publik untuk menjamin pelayanan publik yang berkualitas dan relevan (Haryatmoko, 2015:16).

\section{HIRARKI GEREJA INDONESIA}

\subsection{Landasan Teologis Hirarki Gereja}

Gereja yang satu, kudus, Katolik dan Apostolik di dunia ini disusun dan diatur sebagai serikat, lebih khusus lagi sebagai suatu serikat yang dilengkapi dengan jabatan hirarkis (LG 8). Dengan demikian harus digarisbawahi bahwa atas penetapan ilahi para uskup menggantikan para rasul sebagai gembala Gereja. Yesus Kristus telah mendirikan Gereja kudus dengan mengutus para rasul seperti Ia sendiri diutus oleh Bapa. Oleh karena itu struktur hirarkis Gereja bukanlah 
sesuatu yang ditambahkan atau dikembangkan dalam sejarah Gereja tetapi dikehendaki Tuhan dan akhirnya berasal dari Yesus sendiri. Struktur hirarkis Gereja terdiri dari dewan para uskup dengan paus sebagai kepala dan para imam serta diakon (Konferensi Wali Gereja Indonesia, 1996:363)

\subsection{Sejarah terbentuknya Hirarki Gereja Indonesia}

Susunan Hirarki Gereja di Indonesia memperoleh status hukum Negara Republik Indonesia sebagai kelanjutan tradisi sejak jaman Hindia Belanda lewat Staatsblad no. 156 Tahun 1927, tentang Peraturan kedudukan Hukum Perkumpulan Gereja. Berdasarkan Peraturan tersebut maka Hirarki Gereja terdiri atas keuskupan, Kevikepan dan Paroki dan Propinsi Gerejawi. Satu peristiwa penting yang harus dicatat adalah dikeluarkannya Dekrit Takhta Suci Paus Yohanes XXIII pada tanggal 3 Januari 1961, yang menegaskan bahwa Gereja Katolik di Indonesia dapat berdiri sendiri baik secara administratif maupun dalam urusan rumah tangganya. Pimpinan Gereja setempat tidak lagi berada di bawah Takhta Suci di Roma, tetapi para uskup setempat berstatus penuh. (Direktorat Jenderal Bimbingan Masyarakat Katolik Departemen Agama RI, 2003: 12)

Hirarki Gereja Katolik Indonesia terdiri atas propinsi Gerejawi dan Keuskupan. Propinsi Gerejawi membawahi keuskupan-keuskupan yang berdekatan dalam satu wilayah tertentu. Keuskupan merupakan satu lembaga keagamaan menurut hukum Gereja Katolik yang memiliki komisi dan lembaga sesuai dengan bidang tugasnya. Kevikepan merupakan sebuah wilayah gabungan dari paroki-paroki terdekat dan digabungkan menjadi satu kesatuan khusus dalam sebuah wilayah keuskupan untuk memudahkan koordinasi tugas bersama pastor-pastor paroki dalam lingkupnya. Paroki merupakan sebagian dari umat Katolik dalam keuskupan yang penggembalaan dipercayakan kepada seorang imam ( KHK 515) (Direktorat Jenderal Bimbingan Masyarakat Katolik Departemen Agama RI, 2003: 4).

\subsection{Tugas Hirarki dalam Bidang Politik}

Pada prinsipnya peran hirarki berada pada tataran memberikan landasan moral. Sedangkan soal aspirasi serta bentuk praktis keterlibatan, bahkan wujud pilihan politisnya diserahkan pada kebebasan dan pertimbangan masing pribadi. Hirarki Gereja sesuai dengan tingkatannya memiliki komisi/lembaga (pada tingkat Propinsi Gerejawi dan Keuskupan), memiliki seksi-seksi (pada tingkat paroki) dengan program dan kegiatan pastoral yang berfokus pada tuntunan moral (Cahyadi,2006:44). Pendampingan para politisi katolik dalam meningkatkan peran sosiopolitisnya termasuk dalam cakupan tugas komisi/seksi Kerasulan Awam. Program dan kegiatan tersebut disusun untuk jangka waktu satu tahun. Jika dikaitkan dengan program kerja Komisi KERAWAM baik pada tingkat KWI, Keuskupan maupun Paroki selalu ada kesinambungan dan keberlanjutan program dan kegiatan pendampingan para politisi Katolik.

\section{PERAN SOSIAL-POLITIK KAUM AWAM}




\subsection{Fakta Negatif dalam dunia Politik}

Sering terjadi para politisi yang telah memiliki jabatan strategis-politis memiliki idealisme politik yang dibungkus dengan bermacam-macam janji-janji politik. Tetapi sering kali juga ada gap antara apa yang dikatakan dengan apa yang dilakukan. Verbalisme dan sloganisme politik menjadi penyakit yang menggerogoti banyak politisi katolik saat ini. Dampak ikutannya adalah banyak politisi katolik terjebak dalam arus korupsi yang mematikan panggilan dasar untuk memberikan kontribusi positif bagi masyarakat. Kepentingan kekuasaan nampaknya lebih menjanjikan kemapanan dan kenikmatan ketimbang aspirasi masyarakat luas, nilai moral dan iman (Cahyadi,2006:110).

Dalam setiap moment politik ketika elit politik harus menunjukkan komitmen politiknya untuk memperjuangkan kebenaran dan keadilan, sering kali pertimbangan politik praktis dan sikap pragmatis lebih mewarnai kehidupan para politisi. Akibatnya, politik lebih ditentukan oleh persoalan kepentingan dan keuntungan pribadi. Pada titik ini nafsu untuk mengumpulkan uang sebanyak-banyaknya sangat mengusai para politisi dan juga partai politik. Keyakinan dan aspirasi dengan mudah dimanipulasi demi alasan kekuasaan dan uang. Politik sedang digiring ke ranah pribadi dan kelompok. Sering dilupakan bahwa politik adalah urusan bahkan perjuangan untuk kesejahteraan masyarakat. Dampak dari kerangka berpikir seperti itu adalah politik dan demokrasi berjalan tanpa nilai.

\subsection{Panggilan para Politisi Katolik : Mewujudkan iman}

Berdasarkan pengertian politik di atas, maka keterlibatan politisi katolik dalam bidang politik mencakup politik dalam arti sempit dan politik dalam arti luas. Kalau demikian panggilan politisi katolik dalam bidang politik pasti akan bersentuhan dengan dua realitas politik tersebut. Partisipasi politisi katolik dalam bidang sosial-politik sebagai bentuk perwujudan iman selalu merupakan jawaban atas dua pertanyaan mendasar ini: mengapa dan untuk apa ?

\subsubsection{Mengapa}

Pertanyaan "mengapa" berhubungan dengan motivasi yang menggerakkan politisi katolik untuk terlibat dalam bidang politik. Motivasi merupakan kondisi yang menggerakan hati politisi katolik untuk mencapai tujuan yakni bonum comune. Perihal motivasi memang tidak selalu gampang karena selalu ada dimensi obyektif dan dimensi subyektif. Tetapi sebagai politisi Katolik selalu ada patokan dasar sebagai rambu-rambu dalam bertindak. Ajaran Gereja harus menjadi dasar keterlibatan politisi Katolik. Dengan demikian motivasi politisi Katolik untuk terlibat dalam dunia politik adalah kesadaran akan tanggung jawab atas nasib masyarakat negara, bangsa bahkan umat manusia seluruhnya. Sebab kekotoran politik bukan disebabkan oleh politik itu sendiri tetapi oleh perilaku orang yang terlibat dalam politik (Manzone, 2008: 345). Pada titik inilah perjuangan politik dari para politisi Katolik merupakan salah satu bentuk perwujudan iman. 
Pandangan tentang keselamatan yang utuh dan menyeluruh dapat menjadi motivasi bagi kaum awam untuk berperan dalam dunia politik. Keyakinan ini berkaitan dengan kesadaran iman kristiani yang berdimensi politik itu harus dihayati dalam konteks konkrit yang bersifat politis. Dengan demikian politik menjadi tempat penghayatan dan pengalaman iman. Keprihatinan akan status quo dunia politik yang tidak sesuai dengan tujuannya misalnya melanggar hak-hak asasi manusia, dapat menggerakan kaum awam untuk melibatkan diri dalam politik. Iman para politisi Katolik merupakan iman yang dihayati dalam ruang dan waktu.

\subsubsection{Untuk Apa}

Saat ini peta politik telah berubah, maka terbuka kemungkinan bagi awam katolik yang terlibat dalam dunia politik untuk melakukan konsolidasi demi keterlibatan awam katolik dalam kehidupan sosial politik bangsa. Perjuangan politisi katolik adalah mempertahankan sistem nilai politik agar tetap terfokus pada pembangunan manusia dan masyarakat secara bermartabat. Dengan kata lain nilai-nilai seperti kemanusiaan, keadilan, hukum, demokrasi dan hak-hak asasi lainnya menjadi agenda perjuangan para politisi katolik.

Partisipasi politisi Katolik dalam dunia politik sesungguhnya bukan pada tataran lahiriah yakni penumpukan kekayaan, pencarian nama besar dan pemenuhan ambisi untuk berkuasa dan dengan posisi tersebut boleh membuat keputusan-keputusan politik untuk kepentingan pribadi dan golongan. Partisipasi politisi Katolik sesungguhnya lebih pada tataran promosi nilai-nilai universal yang pada hakekatnya tidak bertabrakan dengan nilai-nilai Kristiani seperti kasih, kebenaran, keadilan, dan solidaritas (Suseno, 2016:39).

\section{PERAN HIRARKI GEREJA}

\subsection{Peran Koordinasi}

Pada umumnya mereka yang telah terlibat dalam bidang politik memiliki kemampuan yang sangat memadai. Banyak dari mereka telah menempuh jenjang pendidikan yang sangat baik dalam berbagai bidang: politik, ekonomi, hukum, budaya, dll. Mereka juga telah terlibat dalam proses politik dan terlibat dalam berbagai partai politik. Karena itu dari sisi pengetahuan dan ketrampilan tidak perlu diragukan.

Masalah yang sering dihadapi adalah banyak politisi berjuang sendiri-sendiri. Tendensi untuk tampil "solo" sangat kuat. Tidak ada jaringan kerja sama yang handal untuk saling mendukung dalam perjuangan menegakan "bonum commune". Kalau toh ada kerja sama, semuanya dilakukan hanya untuk memulus langkah pribadi untuk mendapat posisi dan kedudukan. Selain itu dari sisi sifat kerja sama, yang ada hanya kerja sama "reaktif". Kerja sama yang berorientasi pada penyelesaian kasus-kasus tertentu yang muncul dalam kehidupan bersama. Belum sungguh nampak kerja sama "strategis dan antisipatif" demi tegaknya nilai-nilai kristiani. 
Pada jenjang Konferensi Wali Gereja, Keuskupan dan Paroki, peran Hirarki dalam pendampingan para politisi dilaksanakan oleh Komisi Kerawam. Karena itu komisi Kerawam perlu meningkatkan koordinasi dengan berbagai pihak untuk mendampingi para politisi katolik. Komisi Kerawam perlu memfasilitasi terbentuknya Forum Masyarakat Katolik atau Forum Politisi Katolik (Sularto, 1999:10-11).

\subsection{Peran animasi}

Pembicaraan tentang peran Hirarki dalam meningkatkan partisipasi politisi Katolik dalam dunia politik bermuara pada moralitas dalam berpolitik. Proses pengambilan kebijakan politik dalam berbagai bidang kehidupan harus diletakan dalam kerangka moralitas Katolik. Dewasa ini banyak politisi terjebak dalam arus manipulasi kuasa dan kedudukan; arus mengangkangi moralitas sehingga merasa tidak bersalah ketika melakukan korupsi untuk meraup keuntungan. Dalam konteks itulah para politisi katolik dibantu untuk menegaskan kembali jati diri sebagai politisi Katolik agar teguh dalam prinsip dan sederhana dalam hidup. Dokumen Konsili Vatikan II Gaudium et Spes menegaskan peran Hirarki sebagi berikut :

Hendaknya secara intensif diusahakan pembinaan kewarganegaraan dan politik, yang sekarang ini perlu sekali bagi masyarakat dan terutama bagi generasi muda, supaya semua warga negara mampu memainkan perannya dalam hidup bernegara. Mereka yang cakap atau berbakat hendaknya menyiapkan diri untuk mencapai keahlian politik yang sukar sekaligus luhur, dan berusaha mengamalkannya tanpa memperhitungkan kepentingan pribadi atau keuntungan materiil. Hendaknya mereka secara jujur dan wajar, malahan dengan cinta kasih dan ketegasan politik, membaktikan diri bagi kesejahteraan semua orang (GS. 75).

Dari rumusan di atas dapat ditarik point-point penting sebagai tema animasi bagi para politisi katolik. Terminologi "animasi" dipakai di sini bukan untuk menegasi semua kemampuan yang telah dimiliki oleh para politisi katolik, tetapi untuk mengafirmasi pentingnya animasi spiritual kepada para politisi karena dalam dunia politik selalu ada pertarungan yang sangat hebat antara kepentingan umum dan kepentingan pribadi atau kelompok. Dialog yang intensif antara hirarki dan para politisi katolik yang dirancang bersama akan menjadi "sumur nilai", dan dari sinilah para politisi menimba nilai-nilai iman dan moral sebagai fundamen dalam berpikir dan bertindak sebagai seorang politisi Katolik.

\section{PENUTUP}

Politisi katolik diharapkan untuk terlibat dalam dunia politik dengan landasan nilai-nilai kristianiani: kebenaran dan keadilan. Ini merupakan panggilan sekaligus tantangan. Panggilan berhubungan dengan martabat permandian yang melekat dalam diri para politisi katolik sehingga orientasi para politisi katolik adalah membangun dunia dan masyarakat secara bermartabat sesuai rencana Allah sendiri. Tantangan berhubungan dengan munculnya berbagai tawaran: uang, kuasa dan popularitas diri yang bisa mengaburkan motivasi dasar para politisi katolik untuk berjuang demi kesejahteraan bersama. Dalam konteks itulah dibutuhkan pendampingan yang berkelanjutan dari hirarki Gereja. 


\section{Kepustakaan:}

Cahyadi, Krispurwaana. Katolik dan Politik. Jakarta: Obor, 2006.

Direktorat Jenderal Bimbingan Masyarakat Katolik Departemen Agama RI. Hirarki Gereja Katolik Di Indonesia. 2003.

Go, Pit. Peran serta Orang Katolik dalam Politik. Malang: Dioma, 1990.

Haryatmoko. Etika Publik, Untuk Integritas Pejabat Publik dan Politisi. Yogyakarta: Kanisius, 2015.

Konferensi Wali Gereja Indonesia. Iman Katolik, Buku Informasi dan Referensi. Yogyakarta: Kanisius, 1996.

Manzone, Gianni. Uma Comunita di Liberta, Introduzione alla Teologia Sociale. Edizioni Messagero Padova, 2008.

Sudarmanto, YB. Agama dan Politik Antikekerasan. Yogyakarta: Kanisius, 1989.

Sularto (Editor). Visi Sosial Politik, Tantangan dan Kemungkinan. Yogyakarta: Kanisius, 1999.

Suseno, Franz Magnis. Etika Politik, Prinsip Moral Dasar Kenegaraan Modern. Yogyakarta: Kanisius, 2016. 